Nig. J. Biotech. Vol. 36(2): 139 -149(Dec 2019)

ISSN: 01891731

Available online at

http://www.ajol.info/index.php/njb/index

and www.biotechsocietynigeria.org

DOI: https://dx.doi.org/10.4314/njb.v36i2.14

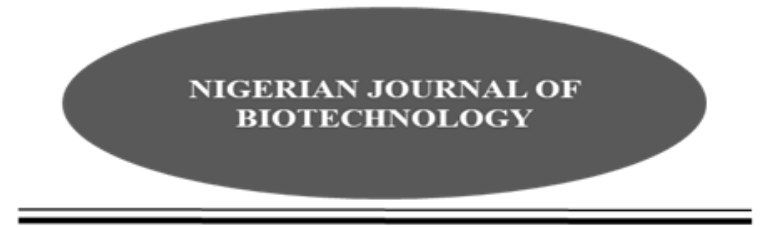

\title{
Phytoremediation of diesel and spent engine oil contaminated soil using Kariya (Hildergardia barteri Mast.) seedlings
}

\author{
Olajuyigbe S.0.1* , Fayinminnu 0.0. ${ }^{2}$, Ayoade A.0. ${ }^{1}$ \\ ${ }^{1}$ Department of Forest Production and Products, University of Ibadan, Nigeria \\ ${ }^{2}$ Department of Crop Protection and Environmental Biology, University of Ibadan, Nigeria
}

\begin{abstract}
Using a completely randomized design experiment, the effect of different levels of diesel and spent engine oil contamination $(0 \mathrm{~mL} / \mathrm{kg}, 25 \mathrm{~mL} / \mathrm{kg}, 50 \mathrm{~mL} / \mathrm{kg}$ and $75 \mathrm{~mL} / \mathrm{kg}$ of soil) on growth performance (seedling height, collar diameter, number of leaves and biomass accumulation) of Hildergardia barteri seedlings were assessed for twelve weeks. The concentration of Lead, Nickel, Copper and Zinc in the plant parts were also determined. Data were analysed using descriptive and inferential statistics at $P<0.05$ level of significance. There were significant differences in the effects of diesel and spent engine oil on growth performance of seedlings based on contamination levels. Control treatment had the highest height $(92.43 \pm 5.13 \mathrm{~cm})$, collar diameter $(16.23 \pm 0.98 \mathrm{~mm})$, number of leaves $(11.21 \pm 0.47)$ and total biomass $(33.01 \pm 12.79 \mathrm{~g})$. Seedlings exposed to $50 \mathrm{~mL} / \mathrm{kg}$ treatments had the least height (diesel oil: $78.21 \pm 7.22 \mathrm{~cm}$; spent engine oil: $79 \pm 6.24 \mathrm{~cm}$ ); those exposed to $75 \mathrm{~mL} / \mathrm{kg}$ contamination had the least collar diameter (diesel oil: $8.85 \pm 1.05 \mathrm{~mm}$, spent engine oil: 12.02 $\pm 1.01 \mathrm{~mm}$ ), while seedlings treated with $50 \mathrm{~mL} / \mathrm{kg}$ diesel oil (2.21 \pm 0.37$)$ and $75 \mathrm{~mL} / \mathrm{kg}$ spent engine oil $(4.79 \pm 0.55)$ had the lowest number of leaves. Heavy metal bio-accumulation ranges were: Lead: $0.17-0.39 \mathrm{mg} / \mathrm{kg}$, Nickel: $0.09-0.45 \mathrm{mg} / \mathrm{kg}$, Copper: $0.54-1.08 \mathrm{mg} / \mathrm{kg}$, Zinc: $0.88-1.58 \mathrm{mg} / \mathrm{kg}$. The ability of the seedlings to survive and bio-accumulate heavy metals indicate the potential phytoremediation capabilities of Hildergardia barteri.
\end{abstract}

Keywords: phytoextraction, hydrocarbon derivatives, growth inhibition, Hildergardia barteri *Corresponding author: so.olajuyigbe@mail.ui.edu.ng, lekito2010@gmail.com, +2348079279357

\section{Introduction}

Pollution is one of the major global problems that results from the use of fossil fuels for powering machines in various industries. Many of these industries have been found culpable in the discharge of heavy metal pollutants such as Cadmium, Copper, Lead, Nickel, and Zinc into the environment (Chen and Chen, 2001). Fossil fuel consumption has also been implicated as a major cause of environmental pollution, particularly with the increasing human population. Oil pollution, which is the contamination of the environment by liquid hydrocarbon causes toxicity to plants and animals in terrestrial and aquatic ecosystems and makes them less productive
(Wyszkowski and Ziólkowska, 2008; Agbogidi and Enujeke, 2012).

Two major hydrocarbon derivatives from crude oil that are complicit in environmental pollution are diesel and spent engine oils. These affect the health and socio-economic wellbeing of communities; whose primary source of livelihoods are strongly dependent on agricultural and aquatic ecosystems. The pollutants reduce the available oxygen in the soil, modify soil physical and chemical properties as well as destroy the micro and macro organisms in the soil. For instance, diesel oil spillage increases soil acidity which results in the destruction of different life forms (Wyszkowski 
Olajuyigbe et al./ Nig. J. Biotech. Vol. 36 Num. 2: 139 - 149 (December 2019)

and Ziólkowska, 2008; Olajuyigbe and Aruwajoye, 2014).

Unfortunately, the clean-up of hydrocarbon derivative polluted sites have depended on physical, chemical and thermal processes which use highly sophisticated, rigorous and expensive engineering techniques that sometimes have debilitating effects on the environment. Hence, research efforts have been exploring the potentials of biological techniques such as phytoremediation as cost effective methods for cleaning of hydrocarbon derivative polluted sites (Frick et al., 1999; Capuana, 2011). This in situ remediation technique utilizes the inherent capabilities of growing plants to bioaccumulate substances. It is an ecologically friendly and solar-energy driven clean-up technology, in which natural processes cleanse nature. As the plants grow and are harvested, they passively remediate low to moderate levels of contamination in the growing medium. Hence, phytoremediation can be used to clean up metals, pesticides, solvents, explosives, crude oil, poly-aromatic hydrocarbons, and landfill leachates in soils, sludge, sediments and water bodies (Ghosh and Singh, 2005).

The high capacity for nutrient uptake and biomass accumulation by plants highlight their heavy metal extraction capabilities from soils over time (Dietz and Schnoor, 2001; Olajuyigbe and Aruwajoye, 2014; Olajuyigbe and Sijuola, 2015). In particular, tree species possess attributes that make them potential candidates for phytoremediation. They produce large quantities of above and below ground biomass, provide aesthetic and economic values, and develop deeply penetrating root systems (Ghosh and Singh, 2005; Yang et al., 2005). Hence, there is need for empirical information on the phytoremediation qualities of tropical trees, particularly hardy species that are known to survive and thrive under difficult conditions. Previous studies have shown the phytoremediation potentials of tropical species such as Gmelina arborea (Alamu et al., 2012); Treculia africana (Agbogidi et al., 2011); Moringa oleifera (Agbogidi and Ilondu, 2013); Terminalia ivorensis (Olajuyigbe and Sijuola, 2015), Khaya senegalensis and Terminalia superba (Olajuyigbe and Aruwajoye, 2014), and Jatropha curcas (Idowu and Fayinminnu, 2015).

Hildergardia barteri (Mast.) is a widely distributed, deciduous, ornamental tropical tree species from the Malvaceae family. The species, commonly known as 'Kariya', is found in tropical dry deciduous woodlands of West Africa from
Ivory Coast to Nigeria to Cameroun. It is a prolific pioneer species, which flowers by the second year of planting, grows to heights of approximately $30 \mathrm{~m}$ and produces an underutilized oilseed. Its ornamental qualities make it of high aesthetic and beautification value, because it produces bright, scarlet flowers and golden pods. This highly specialized species is able to colonize rock outcrops and exposed shallow soils without restraint. It has a unique, large heart-shaped leaf structure and green bark which allows the species to maximize the use of solar radiation for photosynthesis during the wet and dry seasons, even after shedding its leaves (Zaborsky, 2009).

This study assessed the capability of Hildergardia barteri seedlings to survival, grow and bio-accumulate heavy metals in diesel and spent engine oil contaminated soils. Specifically, the study determined the survival rate of the seedlings in varying concentrations of diesel and spent engine oils. It determined the early growth performance of the seedlings, assessed biomass accumulation and the phytoextraction processes for Lead, Nickel, Zinc and Copper.

\section{Materials and Methods Study Area}

The experiment was conducted under controlled conditions in the nursery of the Department of Forest Production and Products, University of Ibadan, Nigeria. The site is located in southwest Nigeria along latitude $7^{\circ} 26^{\prime} 45^{\prime \prime}$ $7^{\circ} 27^{\prime} 31^{\prime \prime} \mathrm{N}$ and longitude $3^{\circ} 53^{\prime} 31^{\prime \prime}-3^{\circ} 54^{\prime} 14^{\prime \prime} \mathrm{E}$, at an altitude of $277 \mathrm{~m}$ above sea level. The climate has distinct wet (April - October) and dry (November - March) seasons, with a mean annual temperature which ranges from $22^{\circ} \mathrm{C}$ $34^{\circ} \mathrm{C}$, while the mean annual rainfall is 1300 $\mathrm{mm}$.

\section{Experimental Procedure}

Unpolluted topsoil was sieved using $2 \mathrm{~mm}$ sieve to remove stones, roots and debris. The soil was then contaminated with diesel and spent engine oils at four contamination levels: $0 \mathrm{~mL} / \mathrm{kg}, 25$ $\mathrm{mL} / \mathrm{kg}, 50 \mathrm{~mL} / \mathrm{kg}$ and $75 \mathrm{~mL} / \mathrm{kg}$ of topsoil. These were thoroughly mixed before filling $5 \mathrm{~kg}$ of contaminated soil into large polythene pots and allowing the mixtures to stabilize for 2 weeks. Subsequently, six month old uniformly growing seedlings were introduced to the polythene pots (one per pot) containing contaminated soil. The experiment was laid out in a completely randomized design with each treatment replicated twenty times and watered 
Olajuyigbe et al./ Nig. J. Biotech. Vol. 36 Num. 2: 139 - 149 (December 2019)

daily. The seedling growth was monitored for twelve weeks with fortnight measurements of total height $(\mathrm{cm})$, collar diameter $(\mathrm{mm})$ and number of leaves. Monthly destructive sampling was used to determine the biomass accumulated by $H$. barteri seedlings. For biomass accumulation determination, three seedlings were selected, uprooted, washed and sectioned into roots, stems and leaves, and initial (fresh) weights were determined. The seedling components (leaves, stem and roots) were then oven dried at $70^{\circ} \mathrm{C}$ until a constant weight was achieved. Total biomass was obtained by summing up the biomass of the various components.

\section{Heavy Metal Analysis}

After twelve weeks of growth, the concentrations of Lead, Copper, Nickel and Zinc present in the roots, stem and leaves of seedlings growing in varying levels of the contaminated soil were determined. The oven dried samples were milled, mixed and homogenized before storing in separate plastic bags until acid digestion was carried out.

For acid digestion, $0.5 \mathrm{~g}$ of milled samples were placed in $250 \mathrm{ppm}$ digestion tubes and $10 \mathrm{ml}$ of Nitric acid $\left(\mathrm{HNO}_{3}\right)$ was added to each tube. The samples were heated for 45 minutes at $90^{\circ} \mathrm{C}$, then the temperature was increased to $150^{\circ} \mathrm{C}$, and the sample boiled for 8 hours until a clear solution was obtained. The solution was filtered and the filtrate transferred quantitatively into a $25 \mathrm{ml}$ volumetric flask. Heavy metal analysis was carried out using an Atomic Absorption Spectrophotometer (Buck Scientific Model 210/211 VGP) to determine the presence and concentration of Copper, Nickel, Lead and Zinc in seedlings grown in the different treatments (AOAC, 2005).

\section{Data Analysis}

Data were analysed using a two-way analysis of variance (ANOVA) and means found to differ significantly were separated using Holm Sidak test of comparison.

\section{Results and Discussion \\ Results}

Survival rate varied among treatments with $100 \%$ survival recorded for seedlings in $0 \mathrm{~mL} / \mathrm{kg}$ (control) and $25 \mathrm{~mL} / \mathrm{kg}$ diesel oil contaminated soil. While seedlings transplanted in the 50 $\mathrm{mL} / \mathrm{kg}$ and $75 \mathrm{~mL} / \mathrm{kg}$ diesel oil treatments had $95 \%$ and $90 \%$ survival rates, respectively. Seedling mortality occurred between 4 to 8 weeks of the experiment. Similarly, there was a $100 \%$ survival for seedlings exposed to 25 $\mathrm{mL} / \mathrm{kg}$ and $50 \mathrm{~mL} / \mathrm{kg}$ spent engine oil contaminated soil, while those exposed to 75 $\mathrm{mL} / \mathrm{kg}$ spent engine oil contamination recorded $95 \%$ survival rate. There were significant differences in the main effect of contamination levels on seedling height for both diesel oil $(P<$ $0.001)$ and spent engine oil $(P<0.001)$ contaminated soils. Whereas, there were no significant differences in the main effect of time of experiment (diesel oil: $P=0.594$; spent engine oil: $P=0.476$ ) and its interaction with contamination levels (diesel oil: $P=0.978$; spent engine oil: $P=1.00)$. The post-hoc test revealed that only control treatments $(0 \mathrm{~mL} / \mathrm{kg})$ differed from the other levels of contamination (Figs. 1 and 2). After twelve weeks, control treatments had the highest mean height $(92.43 \pm 5.13 \mathrm{~cm})$, while seedlings exposed to 50 $\mathrm{mL} / \mathrm{kg}$ of diesel oil contamination (78.21 7.22 $\mathrm{cm})$ and $50 \mathrm{~mL} / \mathrm{kg}$ of spent engine oil contamination $(79 \pm 6.24 \mathrm{~cm})$ had the least.

There were significant differences in the main effects of contamination levels $(P<0.001)$ and time of experiment $(P<0.001)$ as well as their interaction $(P=0.005)$ on collar diameter of seedlings growing in diesel oil contaminated soils. In the same vein, significant differences were observed for the main effect of contamination levels $(P<0.001)$ and time of experiment $(P<0.009)$ on collar diameter of seedlings growing in spent engine oil contaminated soils. However, there was no significant interaction effect $(P=0.847)$. 
Olajuyigbe et al./ Nig. J. Biotech. Vol. 36 Num. 2: 139 - 149 (December 2019)

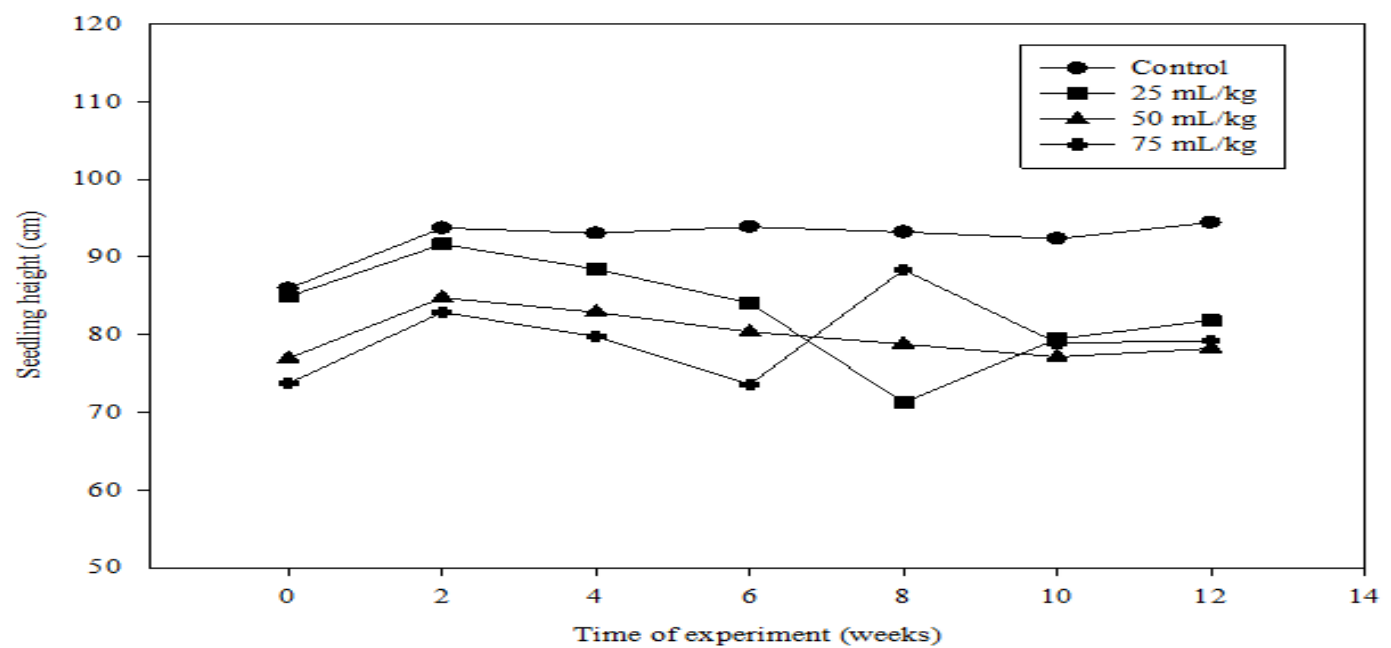

Figures 1: Total height of Hildergardia barteri seedlings growing in soils subjected to varying levels of diesel oil contamination for twelve weeks (each data point represents mean of seedling population)

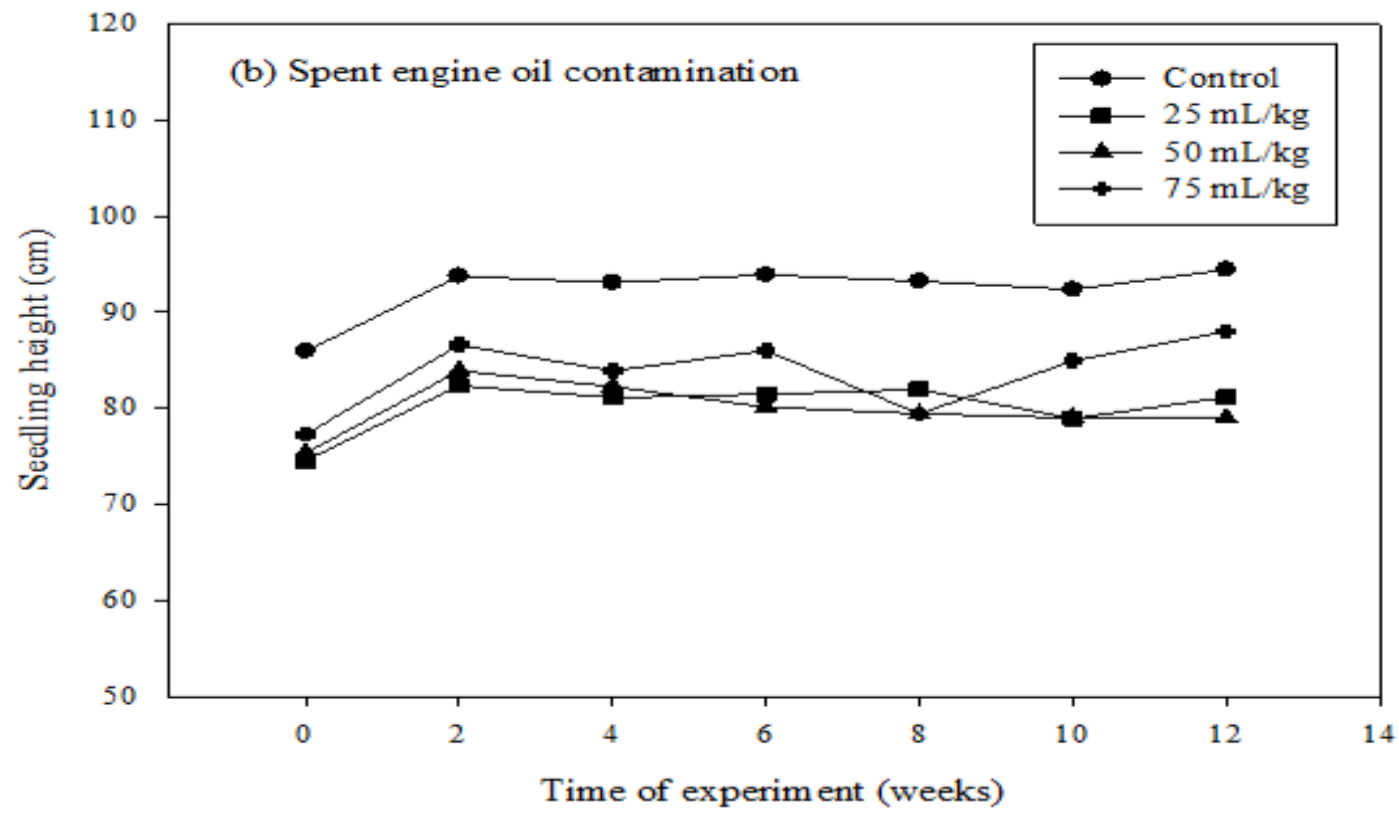

Figures 2: Total height of Hildergardia barteri seedlings growing in soils subjected to varying levels of spent engine oil contamination for twelve weeks (each data point represents mean of seedling population)

The post hoc test revealed that seedlings exposed to $50 \mathrm{~mL} / \mathrm{kg}$ and $75 \mathrm{~mL} / \mathrm{kg}$ spent engine oil treatments had similar limiting effects on collar diameter development (Figs. 3 and 4). 
Olajuyigbe et al./ Nig. J. Biotech. Vol. 36 Num. 2: 139 - 149 (December 2019)

After twelve weeks, the mean collar diameter was highest for seedlings under control treatment $(16.23 \pm 0.98 \mathrm{~mm})$, while seedlings exposed to $75 \mathrm{~mL} / \mathrm{kg}$ treatment had the least (diesel oil: $8.85 \pm 1.05 \mathrm{~mm}$, spent engine oil: $12.02 \pm 1.01 \mathrm{~mm})$. The limiting effect of the soil contamination began to manifest after the 8th week of transplanting. However, seedlings growing in $25 \mathrm{~mL} / \mathrm{kg}$ treatments were able to tolerate and continue height and collar diameter development, despite the contamination.

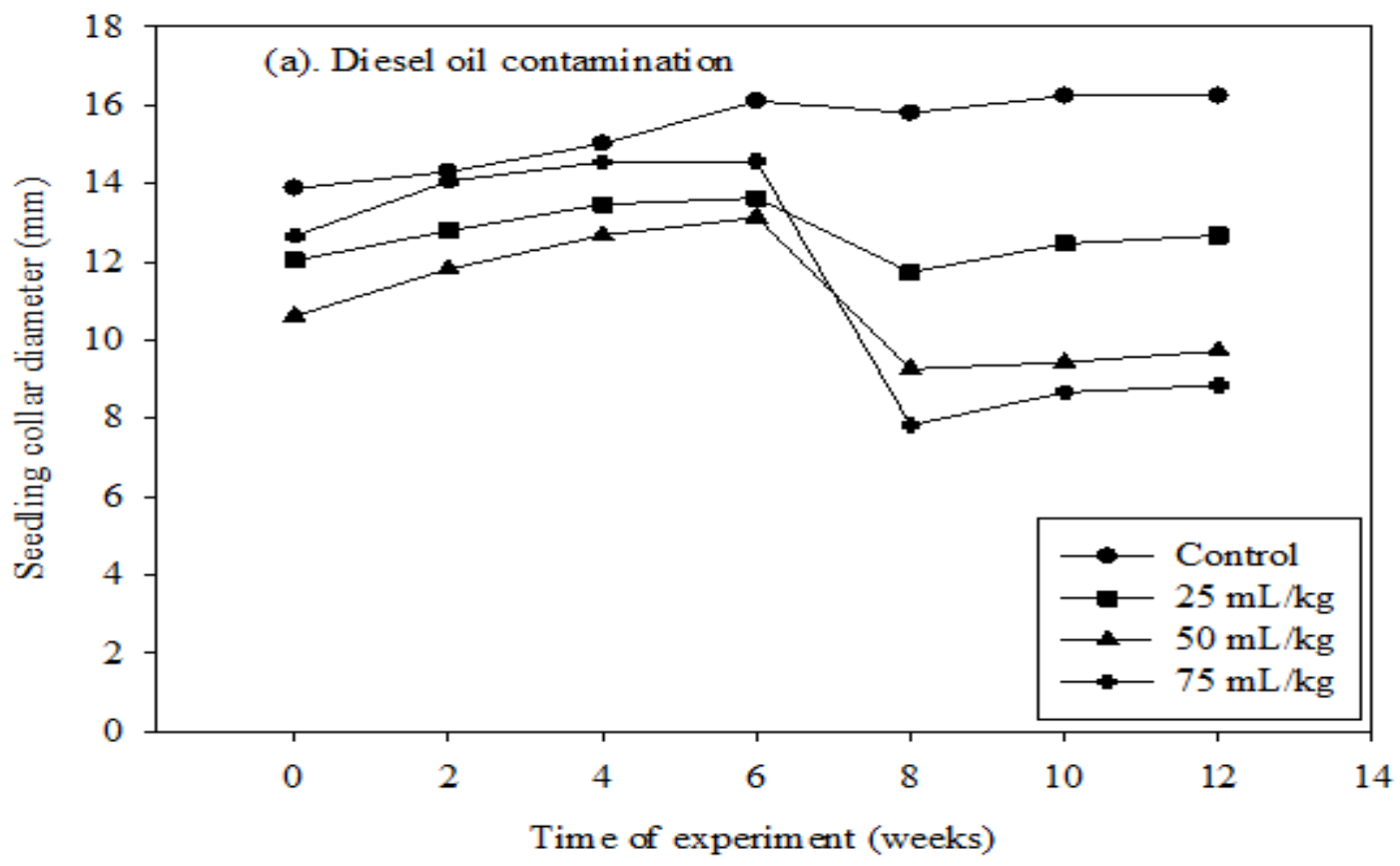

Figures 3: Collar diameter of Hildergardia barteri seedlings growing in soils subjected to varying levels of diesel oil contaminations for twelve weeks (each data point represents mean of seedling population)

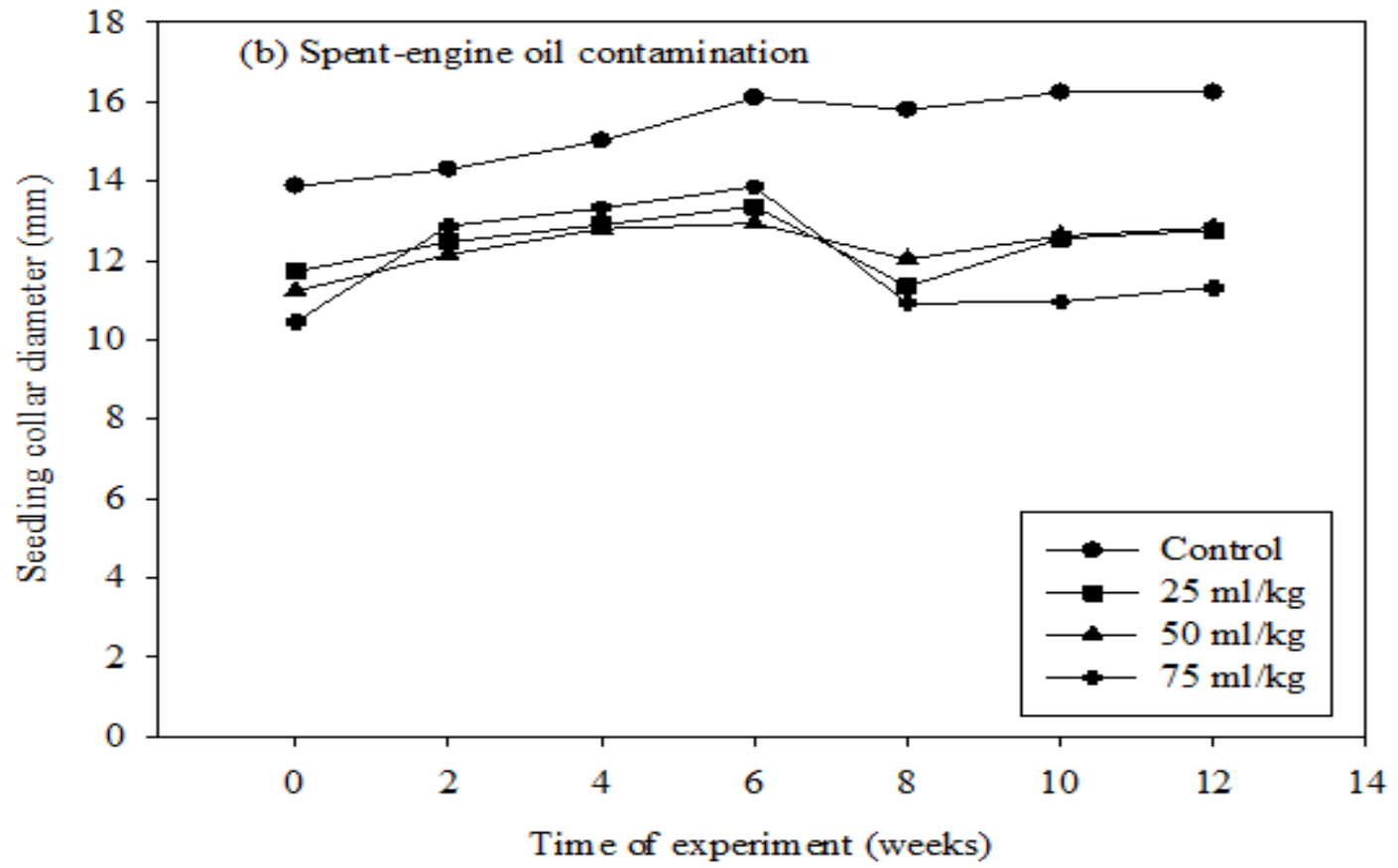


Olajuyigbe et al./ Nig. J. Biotech. Vol. 36 Num. 2: 139 - 149 (December 2019)

Figures 4: Collar diameter of Hildergardia barteri seedlings growing in soils subjected to varying levels of spent engine oil contaminations for twelve weeks (each data point represents mean of seedling population)

There were significant differences in the main and interaction effects $(P<0.001)$ of contamination levels $(P<0.001)$ and time of experiment $(P<0.001)$ on the number of leaves produced by seedlings growing in diesel oil contaminated soils. Only $50 \mathrm{~mL} / \mathrm{kg}$ and 75 $\mathrm{mL} / \mathrm{kg}$ treatments did not differ from each other (Fig. 5). Similarly, significant differences were observed for the main and interaction effects ( $P$ $=0.001)$ of contamination levels $(P<0.001)$ and time of experiment $(P<0.001)$ on the number of leaves produced by seedlings growing in spent engine oil contaminated soils. There was a continuous drop in the number of leaves of seedlings exposed to $50 \mathrm{~mL} / \mathrm{kg}$ and $75 \mathrm{~mL} / \mathrm{kg}$ of spent engine oil contaminated soils (Fig. 6). After twelve weeks, the mean number of leaves was highest for seedlings under control treatment $(11.21 \pm 0.47)$, while seedlings exposed to 50 $\mathrm{mL} / \mathrm{kg}$ diesel oil treatment $(2.21 \pm 0.37)$ and 75 $\mathrm{mL} / \mathrm{kg}$ spent engine oil treatment $(4.79 \pm 0.55)$ recorded values.

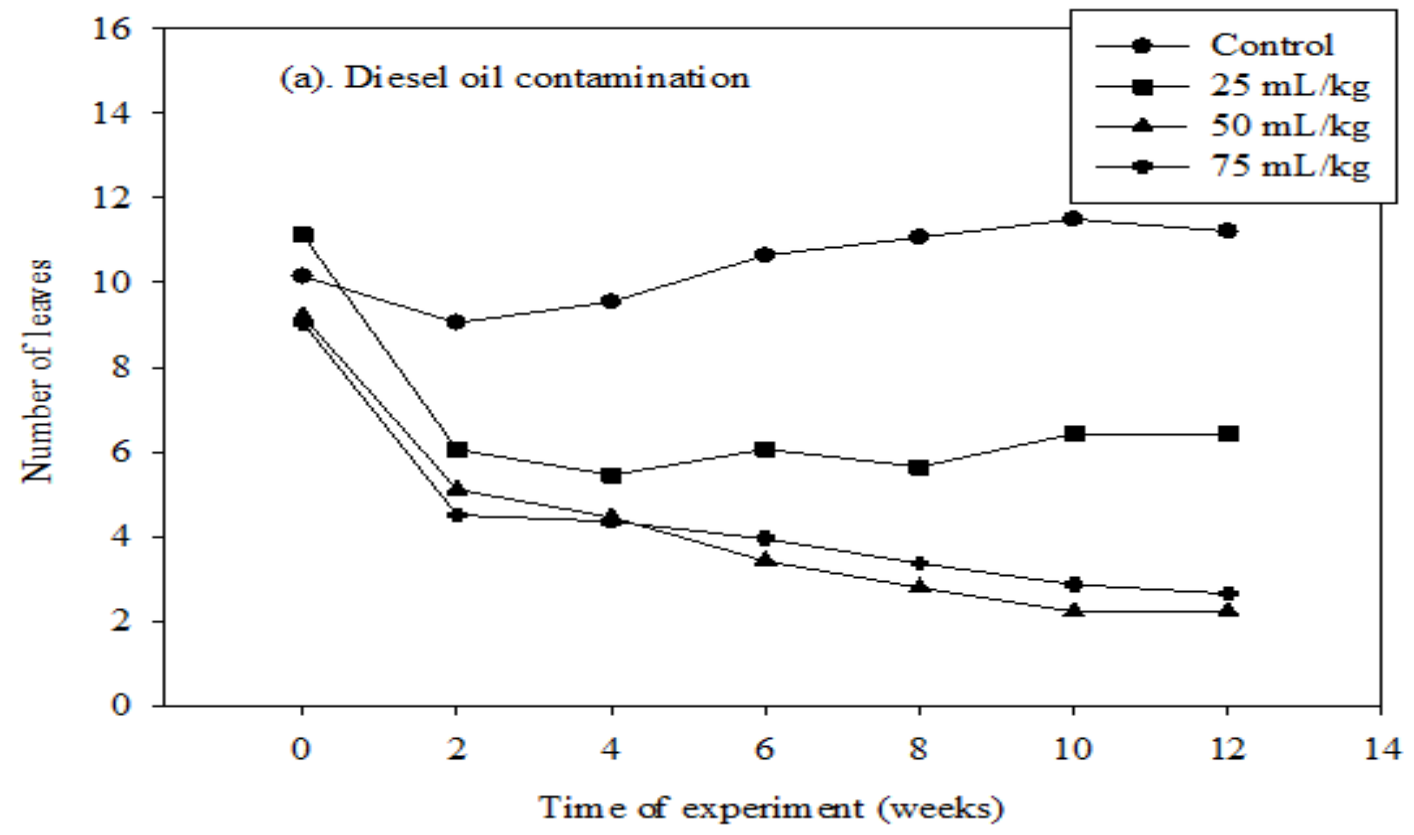

Figures 5: Number of leaves on Hildergardia barteri seedlings growing in soils subjected to varying levels of diesel oil contamination for twelve weeks (each data point represents mean of seedling population)

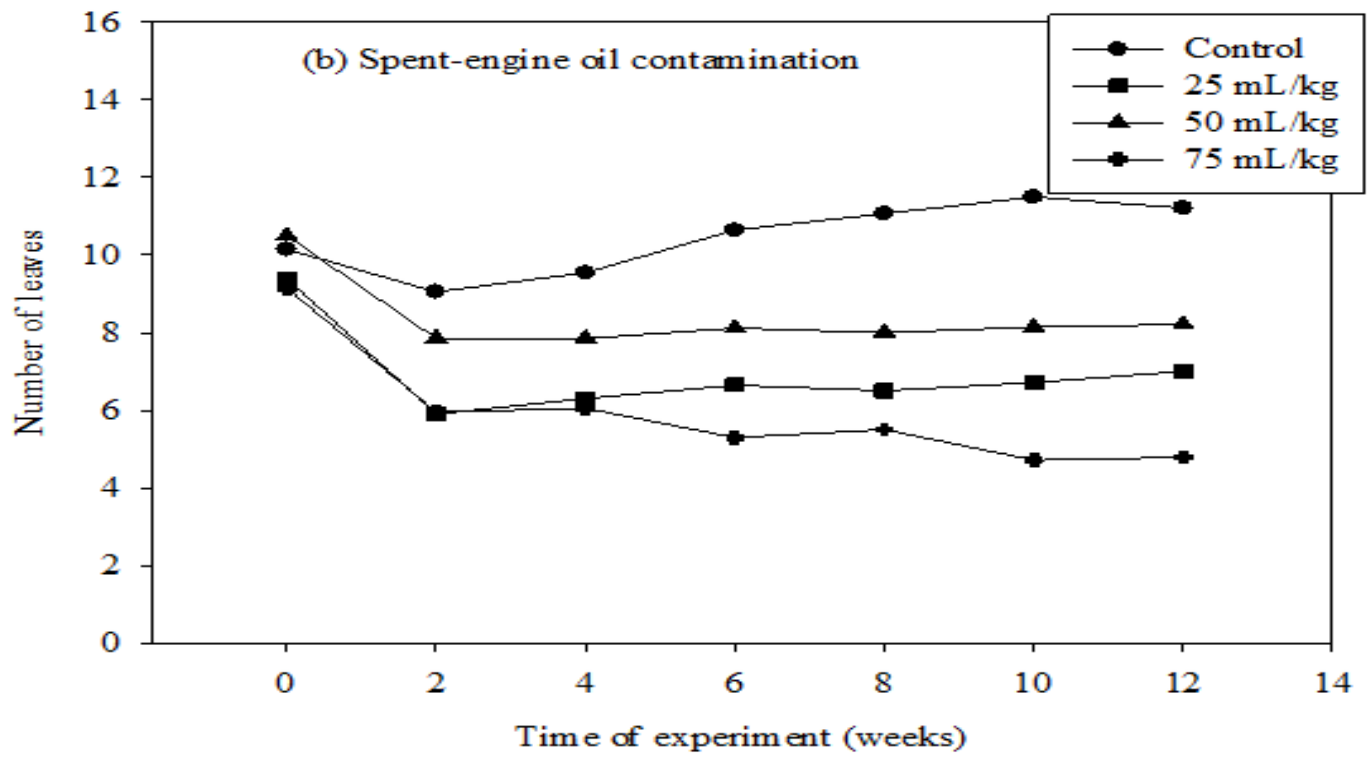


Figures 6: Number of leaves on Hildergardia barteri seedlings growing in soils subjected to varying levels of spent engine oil contamination for twelve weeks (each data point represents mean of seedling population)

After twelve weeks, the highest biomass $(33.01 \pm 12.79 \mathrm{~g})$ was recorded for control treatment, while the least was recorded for seedlings exposed to $50 \mathrm{~mL} / \mathrm{kg}$ diesel oil $(5.6 \pm 3.50 \mathrm{~g})$ and $25 \mathrm{~mL} / \mathrm{kg}$ spent engine oil $(15.12 \pm 5.83 \mathrm{~g})$ contaminations, respectively.
The biomass allocated to stems were highest followed by roots (Figs. 7 and 8). However, biomass accumulation did not follow a consistent trend with increase in contamination levels for both types of hydrocarbon oil derivatives.

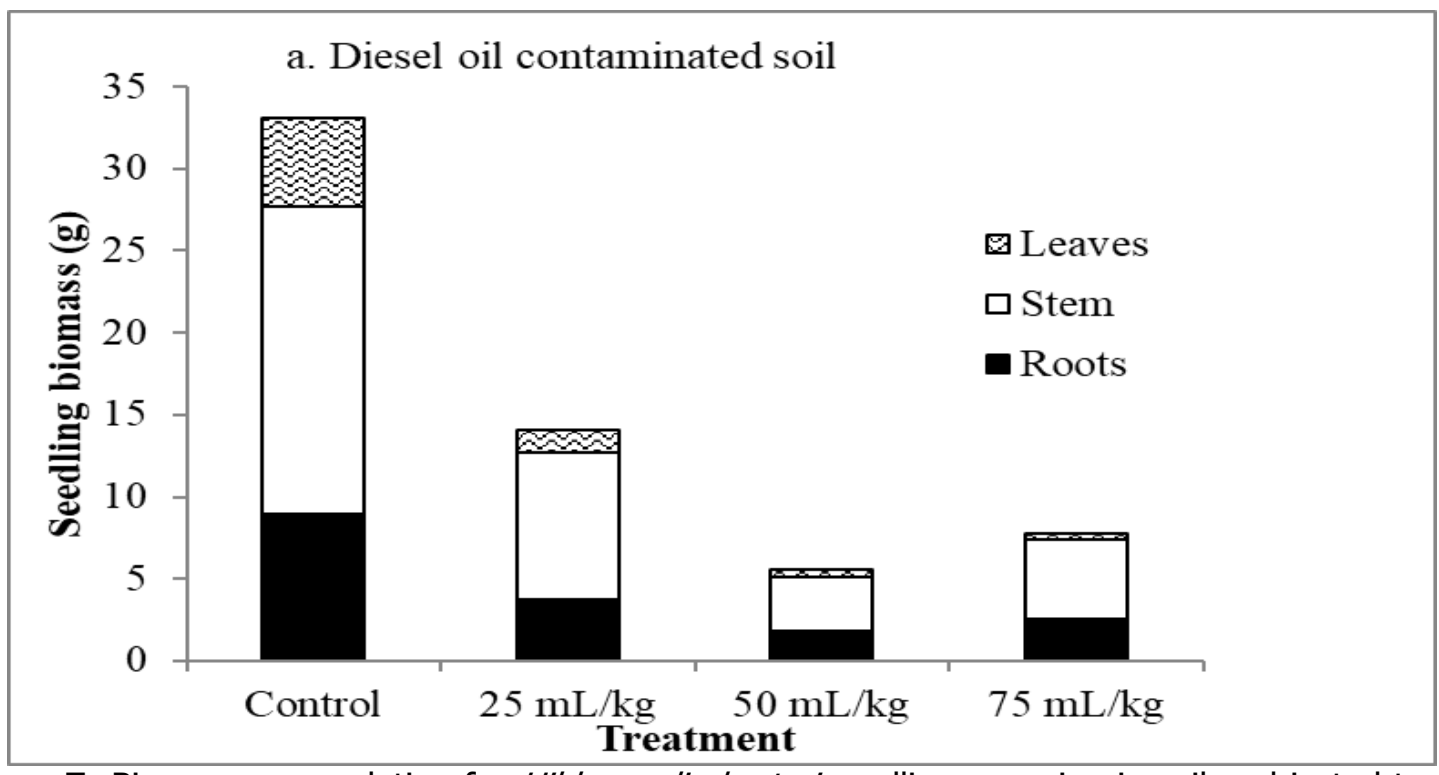

Figures 7: Biomass accumulation for Hildergardia barteri seedlings growing in soils subjected to varying levels of diesel oil contamination for twelve weeks (biomass partitioned into leaf, stem and root components)

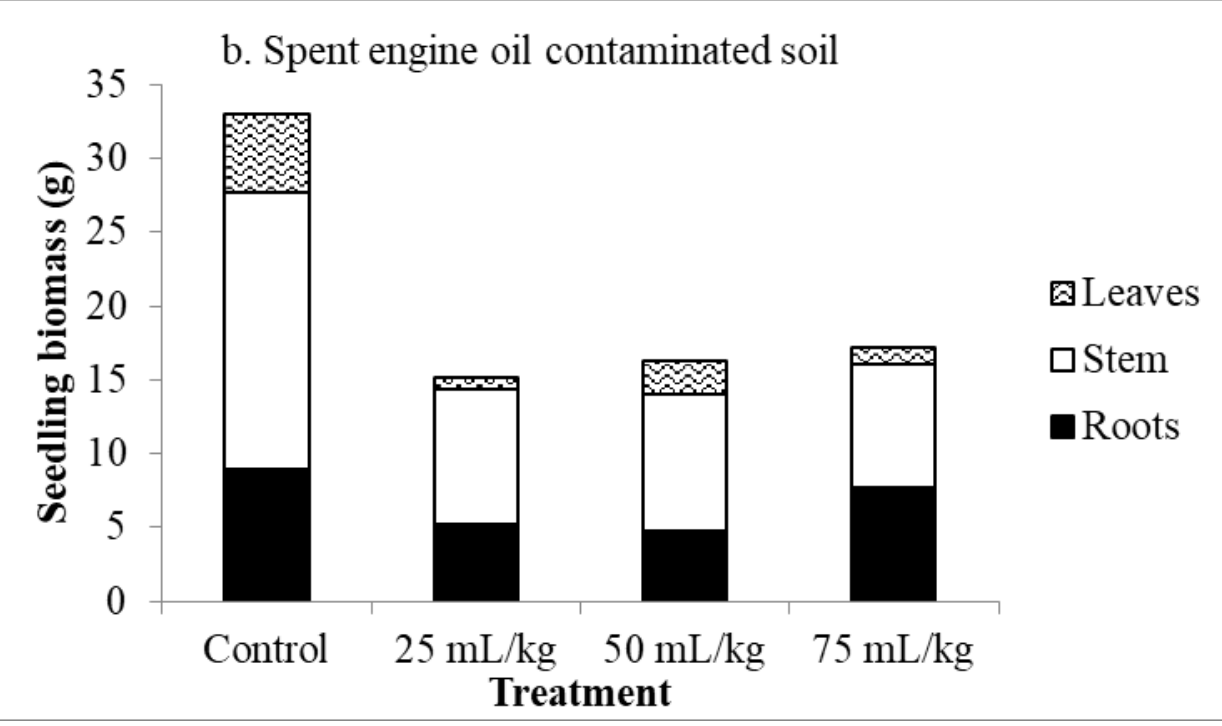


Figures 8: Biomass accumulation for Hildergardia barteri seedlings growing in soils subjected to varying levels of spent engine oil contamination for twelve weeks (biomass partitioned into leaf, stem and root components)

At the end of the experiment, there were no traces of Lead and Nickel in the above ground (stem and leaves) parts of the seedlings. Although, there was no trace of Lead in the seedlings of the control treatment, the heavy metal was bio-accumulated in the roots of the seedlings growing in both diesel and spent engine oil contaminated soils. The Lead content increased with level of contamination for diesel oil contaminated seedlings. However, it was higher in the roots of seedlings exposed to 50 $\mathrm{mL} / \mathrm{kg}$ than those exposed to $75 \mathrm{~mL} / \mathrm{kg}$ spent engine oil. Nickel content increased with level of contamination for diesel oil but did not follow a particular pattern for spent engine oil contaminated soils (Table 1). Nevertheless, Nickel accumulation was highest for the roots of seedlings exposed to $75 \mathrm{~mL} / \mathrm{kg}$ of both diesel and spent engine oil contaminations.

Copper and zinc were found in both below and above ground plant parts with higher concentrations observed in the shoot than roots. The plants were able to translocate the metals to their shoot (leaves and stems). Copper increased with level of contamination for diesel oil but did not follow a similar pattern for spent engine oil, with seedlings exposed to $50 \mathrm{~mL} / \mathrm{kg}$ spent engine oil contamination recording the highest concentration of copper. For zinc, the level of bio-accumulation was lower for seedlings exposed to $75 \mathrm{~mL} / \mathrm{kg}$ of diesel and spent engine oil contaminations than those exposed to $50 \mathrm{~mL} / \mathrm{kg}$ treatment (Table 1 ).

Table 1. Bio-accumulation of heavy metals in above and below ground parts of Hildergardia barteri seedlings exposed to diesel oil and spent engine oil contaminated soils for twelve weeks

Diesel oil contamination

Plant part
Spent engine oil contamination

$\begin{array}{llll}75 & 25 & 50 & 75 \\ (\mathrm{mg} / \mathrm{kg}) & (\mathrm{mg} / \mathrm{kg}) & (\mathrm{mg} / \mathrm{kg}) & (\mathrm{mg} / \mathrm{kg})\end{array}$

\begin{tabular}{|c|c|c|c|c|c|c|c|}
\hline \multicolumn{8}{|c|}{ Lead } \\
\hline Roots & $\begin{array}{l}\text { No } \\
\text { traces }\end{array}$ & 0.32 & 0.31 & 0.39 & 0.17 & 0.32 & 0.25 \\
\hline \multicolumn{8}{|c|}{ Nickel } \\
\hline Roots & 0.13 & 0.23 & 0.35 & 0.45 & 0.11 & 0.09 & 0.12 \\
\hline
\end{tabular}

\section{Copper}

\begin{tabular}{llllllll}
\hline Roots & 0.26 & 0.33 & 0.27 & 0.50 & 0.41 & 0.26 & 0.29 \\
Shoot & 0.29 & 0.35 & 0.51 & 0.58 & 0.44 & 0.61 & 0.50 \\
Total & 0.54 & 0.69 & 0.78 & 1.08 & 0.85 & 0.87 & 0.79 \\
\hline $\begin{array}{l}\text { Transfer factor } \\
\text { (shoot to root }\end{array}$ & 1.11 & 1.06 & 1.89 & 1.16 & 1.07 & 2.35 & 1.72 \\
\hline
\end{tabular}


Olajuyigbe et al./ Nig. J. Biotech. Vol. 36 Num. 2: 139 - 149 (December 2019)

ratio)

\begin{tabular}{lccccccc}
\hline \multicolumn{7}{c}{ Zinc } \\
\hline Roots & 0.46 & 0.81 & 0.55 & 0.46 & 0.74 & 0.49 & 0.50 \\
\hline Shoot & 0.42 & 0.43 & 1.03 & 0.62 & 0.42 & 0.56 & 0.55 \\
\hline Total & 0.88 & 1.24 & 1.58 & 1.08 & 0.88 & 1.30 & 1.04 \\
\hline $\begin{array}{l}\text { Transfer factor } \\
\text { (shoot to root } \\
\text { ratio) }\end{array}$ & 0.91 & 0.53 & 1.87 & 1.35 & 0.57 & 1.14 & 1.10 \\
\hline
\end{tabular}

\section{Discussion}

The exposure of Hildergardia barteri seedlings to the hydrocarbon pollutants resulted in an initial shock evidenced by the colour of leaves on the seedlings, becoming pale and yellow, while growth was stunted. It also resulted in the death of some seedlings as a result of the toxic effect of pollutants (Claudio et al., 2012). Nevertheless, $100 \%$ survival rate was observed for seedlings exposed to $25 \mathrm{~mL} / \mathrm{kg}$ of diesel oil contamination, while $50 \mathrm{~mL} / \mathrm{kg}$ and $75 \mathrm{~mL} / \mathrm{kg}$ treatments led to the death of some seedlings. Njoku et al. (2009) also reported the mortality of Vigna unguiculata seedlings due to diesel oil contamination of soil, while Fayinminnu and Abimbola (2016) reported that toxicity caused by spent engine oil contamination resulted in the premature death of Solanum lypersicon plants.

Leaf production was affected by the hydrocarbon contaminations, as the number of leaves reduced with increase in the level of contamination (Olajuyigbe and Aruwajoye, 2014). This corroborates the report of Nwoko et al. (2007), who mentioned that spent engine oil contamination hindered the growth and development of Phaseolus vulgaris seedlings. The changing colours and paleness of the leaves, leaf wilting and abscission, as well as darkening of lower portion of the stem region have also been previously attributed to diesel and spent engine oil contamination of soils (Nwoko et al., 2007; Olajuyigbe and Aruwajoye, 2014; Fayinminnu and Abimbola, 2016). The severity of the effects of increasing amount of contamination was initially high until the 4th week of the experiment, after which the leaf production stabilized. Although, leaf production was still lower than those observed for seedlings in the control treatment, which had the most vigorous growth performance. In particular, leaf production allowed for increased photosynthesis and higher biomass production. On the other hand, leaf production fluctuated among the contaminated treatments with most seedlings continuously shedding their leaves. With leaves being the major photosynthetic organ of plants, it is indicative that rate of photosynthesis for seedlings growing in diesel and spent engine oil contaminations were reduced and thus slowing down growth (Olajuyigbe and Sijuola, 2015).

The seedling growth variables reduced with increase in contamination levels confirming the assertion that the limitation of growth by hydrocarbon derivatives is dose dependent (Idowu and Fayinminnu, 2015). In this study, seedling height, collar diameter and leaf production were all limited by increase in diesel and spent engine oil contamination levels. Although the plant continued to grow and develop despite the inhibition. Soil contamination by hydrocarbon derivatives probably inhibited the movement of photosynthates to the roots, and also reduced the movement of soil resources such as water and nutrients from belowground to the aboveground parts (Nwoko et al., 2007; Agbogidi et al., 2013). Hydrocarbons from petroleum products smear plant roots with oily substances, thus limiting respiration and evapotranspiration. In addition, the pollutants limit cell metabolic activities and sometimes change the chemical composition of photosynthates (Capuana, 2011; Olajuyigbe and Aruwajoye, 2014). All through the study, the contaminated soils were inundated with oily water. This confirmed the assertion of Fayinminnu and Abimbola (2016) that water percolation into the soil in oil polluted environments, is inhibited by a waxy film caused by the presence of the hydrocarbon derivatives on the soil surface. 
Olajuyigbe et al./ Nig. J. Biotech. Vol. 36 Num. 2: 139 - 149 (December 2019)

The uptake of heavy metals such as copper and zinc may be an indication that $H$. barteri has the potential to remediate sites with low to medium contamination. This was evidenced by the survival and continued, though reduced growth of the plant species, in hydrocarbon contaminated soils (Nwoko et al., 2007). The ability of Hildergardia barteri to grow in soils contaminated with diesel and spent engine oil suggests that the species may have the ability to volatilize or degrade the toxicants. This is because biomass accumulation progressed despite the growth inhibition caused by the contaminants (Lone et al., 2008). Similar growth responses have been reported for seedlings of Terminalia ivorensis, Terminalia superba and Khaya senegalensis (Olajuyigbe and Aruwajoye, 2014; Olajuyigbe and Sijuola, 2015).

The success of a phyto-extraction process depends on metal removal by the shoot tissues (translocation) from the growth medium. The ability of plants to translocate metals from roots to the shoot was measured using 'transfer factor' (Usman et al., 2009). Transfer factor is the ratio of metal concentrations in the shoot tissue (leaf and stem) to the concentration in the root tissues (Table 1). When transfer factor value is greater than 1 , it indicates that the metals effectively moved from root tissues to shoot (Baker and Brooks, 1989). Copper and Zinc were translocated and accumulated, in the aboveground parts. Copper was phytoextracted into the shoot with $50 \mathrm{~mL} / \mathrm{kg}$ treated seedlings having the highest transfer factor (diesel oil: 1.9; spent engine oil: 2.4). For Zinc, the seedlings exposed to $50 \mathrm{~mL} / \mathrm{kg}$ of diesel oil contamination (1.9) and those exposed to 75 $\mathrm{mL} / \mathrm{kg}$ spent engine oil contamination (1.2) had the highest transfer factors. In this study, the Hildergardia barteri was a poor translocator of Lead and Nickel, from both diesel and spent engine oil contaminated soils. The two heavy metals remained in the roots, a term known as rhizofiltration, a process whereby plants absorb heavy metals and retain them in their roots. This has also been proven to be effective in partial treatment of industrial discharge, agricultural runoff, or acid mine drainage. It has been suggested to be useful for removing Lead, Cadmium, Copper, Nickel, Zinc and Chromium, which are primarily retained within the roots (Chaudhry et al., 1998; Ghosh and Singh, 2005; Fayinminnu and Abimbola, 2016).

\section{Conclusion}

Many species with fast growth rates and high biomass production have been identified for phytoremediation of soil particularly those with hyperaccumulation capacity. The survival, growth and heavy metal uptake by the roots and shoots of Hildergardia barteri suggest that the species could survive under very difficult and toxic conditions. However, the bioaccumulation patterns revealed that low amounts of the heavy metals were absorbed into the plant biomass. The process of phytoremediation was slow and limited and the species may only be able to phyto-extract minimum amounts of heavy metals from diesel and spent engine oil polluted lands. Nevertheless, the plant was able to rhizofiltrate Lead and Nickel in its root system, while the phytoextraction and translocation of copper and zinc occurred in the entire plant system. The tropical tree species was tolerant to concentration levels as high as $75 \mathrm{~mL} / \mathrm{kg}$, for both diesel and spent engine oil and with further evaluation may be considered as a candidate for natural rehabilitation of polluted sites.

\section{References}

Alamu, O., Ojo A. O. and Ogunesan B. A. (2012). Effect of Oil Types as Pollutants on Physiognomic Characteristics of Gmelina arborea in the Tropical Rainforest Zone of Nigeria. Afr. J. Plant Sci. 6(5): 161-165.

Agbogidi, O. M., Edema, N. E. and Agboje, I. (2011). Evaluation of African Bread Fruit (Treculia africana Decene) for Bioremediation in Soils Impacted with Crude Oil. Int. J. Sci. Nat. 2(3): 461-466

Agbogidi, O. M. and Enujeke, E. C., (2012). Effects of Spent Motor Oil on Soil PhysicoChemical Properties and Growth of Arachis hypogaea L. Global J. Biosci. Biotechnol. 1: 7174.

Agbogidi, O. M. and Ilondu, E. M. (2013). Effects of Spent Engine Oil on the Germination and Seedling Growth of Moringa oleifera Lam. Scholarly J. Agric. Sci. 3(6): 239-243.

AOAC (2005). Official Method of Analysis. Association of Official Analytical Chemists Washington DC. 15th edition. P. 11-14.

Baker, A. J. M. and Brooks, R. R. (1989). Terrestrial Higher Plants Which 
Olajuyigbe et al./ Nig. J. Biotech. Vol. 36 Num. 2: 139 - 149 (December 2019)

Hyperaccumulate Metallic Elements: A Review of their Distribution, Ecology and Phytochemistry. Biorecovery 1: 81-126.

Capuana, M. (2011). Heavy Metals and Woody Plants - Biotechnologies for Phytoremediation. iForest 4: 7-15

Claudio, B., Mohammad W., Silvia F. and Laura M. (2012). Effects of Heavy Metals on Morphological Characteristics of Taraxacum officinale Web Growing on Mine Soils in NE Italy. J. Geochem. Explor. 123: 101-108

Chaudhry, T.M., Hayes, W.J., Khan, A.G. and Khoo, C.S., (1998). Phytoremediation: Focusing on Accumulator Plants that Remediate MetalContaminated Soils. Australas. J. of Ecotoxicol. 4: 37-51.

Chen, Y.-C., Chen, M.-H., (2001). Heavy Metal Concentrations in Nine Species of Fishes Caught in Coastal Waters Off Ann-Ping, S.W. Taiwan. J. Food Drug Anal. 9: 107-114.

Dietz, A.C. and Schnoor, J.L., (2001). Advances in Phytoremediation. Environ. Health Perspect. 109 (1): 163-168.

Fayinminnu, O. O. and Abimbola, M. O. (2016). Assessment of Heavy Metals and Total Petroleum Hydrocarbons Accumulation in Tomato (Solanum lycopersicon L.) Grown on Spent Oil Polluted Soil. Nigerian J. Ecol. 15(2):19-29.

Frick, C. M., Farrell, R. E. and Germida, J. J. (1999). Assessment of Phytoremediation as an In-situ Technique for Cleaning Oil-Contaminated Sites. In: Department of Soil Science, SK Canada S7N $5 A 8$ (Editor). Petroleum Technology Alliance of Canada (PTAC) Calgary, AB, Calgary, pp. 88.

Ghosh, M. and Singh, S.P., (2005). A Review on Phytoremediation of Heavy Metals and Utilization of Its Byproducts. Appl. Ecol. Env. Res. 3(1): 1-18.

Idowu, O. D. and Fayinminnu, O. O. (2015). Phytotoxicity Effect of Spent Oil on Jatropha curcas Seedlings used in Soil Phytoremediation. Ethiopian J. Env. Stud. Mgt. 8 (2): 906 - 915.
Lone, M. I., He, Z-I., Stofella, P. J. and Yang, X.e. (2008). Phytoremediation of Heavy Metal Polluted Soils and Water: Progresses and Perspectives. J. Zhejiang Univ. Sci. B, 9 (3): 210-220.

Njoku, K. L., Akinola, M. O. and Oboh, B. O. (2009). Phytoremediation of Crude Oil Contaminated Soil: the Effect of Growth of Gylcine max on the Physico-Chemistry and Crude Oil Contents of Soil. Nat. Sci. 7 (10):7987.

Nwoko, C. O., Okeke, P. N., Agwu, O. O. and Akpan, I. E., (2007). Performance of Phaseolus vulgaris L. in a Soil Contaminated with Spent Engine Oil. Afr. J. Biotechnol., 6(16): 19221926.

Olajuyigbe, S. O. and Aruwajoye, D. A. (2014). Phytoremediation of Diesel Oil Contaminated Soil using Seedlings of Two Tropical Hardwood Species (Khaya senegalensis and Terminalia superba). Int. J. Sci. Eng. Res, 5(6): 1067-1078.

Olajuyigbe, S. O. and Sijuola, T. O. (2015). Phytoextraction of Heavy Metals from Diesel Oil Contaminated Soil using Terminalia ivorensis A. Chev. Seedlings. Ibadan J. Agric. Res., 11 (2): 63-72.

Usman, A. R. A. and Mohammed, H. M. (2009). Effect of Microbial Inoculation and EDTA on the Uptake and Translocation of Heavy Metals by Corn and Sunflower. Chemosphere 76, 893-899.

Wyszkowski, M. and Ziólkowska, A., (2008). Effect of Petrol and Diesel Oil on Content of Organic Carbon and Mineral Components in Soil. Am-Eurasian J. Sustain. Agric. 2(1): 54-60.

Yang, J., McBride, J., Zhou, J. and Sun, Z. (2005). The Urban Forest in Beijing and Its Role in Air Pollution Reduction. Urban For. Urban Green. 3(2): 65-78.

Zaborsky, J. G. (2009). Hildergardia dauphinensis (Malvaceae, Sterculioideae): A New Species from Southeastern Madagascar. Adansonia $31(3)$ : 143-148. 